\title{
Small mammals in the diet of owls in the Masovian Landscape Park and its adjacent areas
}

\author{
Grzegorz LESIŃSKI ${ }^{1}$, Przemysław STOLARZ ${ }^{2}$, Jakub GRYZ ${ }^{3}$, Radosław DĄBROWSKI ${ }^{4}$, Dagny \\ KRAUZE-GRYZ ${ }^{5}$, Przemysław SKRZYPIEC-NOWAK ${ }^{4}$ and Jagoda Świć ${ }^{6}$ \\ ${ }^{1}$ Faculty of Animal Science, Warsaw University of Life Sciences - SGGW, Ciszewskiego 8, 02-787 Warsaw, Poland; \\ e-mail: glesinski@wp.pl \\ ${ }^{2}$ Center for Human Ecology, Kościuszki 24, 05-075 Warsaw-Wesoła, Poland; e-mail: przem.stolarz@gmail.com \\ ${ }^{3}$ Forest Research Institute, Sękocin Stary, Braci Leśnej 3, 05-090 Raszyn, Poland; e-mail: J.Gryz@ibles.waw.pl \\ ${ }^{4}$ Masovian Landscape Park, Sutkowskiego 11, 05-400 Otwock, Poland; \\ e-mails: (RD) radek@parkiotwock.pl,(PS-N) teren@parkiotwock.pl \\ ${ }^{5}$ Faculty of Forestry, Warsaw University of Life Sciences - SGGW, Nowoursynowska 159, 02-776 Warsaw, Poland; \\ e-mail: Dagny.Krauze@wl.sggw.pl \\ ${ }^{6}$ Forestry Management Celestynów, Obrońców Pokoju 58, 05-430 Celestynów, Poland; \\ e-mail: jagodaswic@gmail.com
}

\begin{abstract}
The diet of three owl species was analysed in 32 sites localised in the Masovian Landscape Park and its outskirts to determine the structure of small mammal communities. Study was done in the years 1993-2016, 5,728 vertebrate prey (including 4,001 mammals) were collected. Five species of soricomorphs, six bats, 14 rodents and one species of Carnivora were found. Among mammals, Myodes glareolus had the greatest share in the diet of Strix aluco. Tyto alba most frequently caught Microtus arvalis and Sorex araneus, while Asio otus - M. arvalis and M. oeconomus. Those prey, together with Apodemus flavicollis and A. agrarius, dominated in small mammal communities. One site of Crocidura leucodon was found on the western edge of its range in Poland. The share of bats in the diet of S. aluco was small ( $0.5 \%$ of mammals), Plecotus auritus was most frequent. Muscardinus avellanarius was found in forests of the southern part of the Masovian Landscape Park. It was relatively often caught by S. aluco in favourable habitats. Shares of M. oeconomus, M. agrestis and M. avellanarius in the diet of owls were significantly higher in southern part of the study area remote from Warsaw.
\end{abstract}

Key words: Soricomorpha, Chiroptera, Rodentia, owls' diet composition, Central Poland, the common dormouse, the bicoloured white-toothed shrew

\section{INTRODUCTION}

Relatively few data on small mammals in the Masovian Landscape Park and its surroundings have been published so far. With respect to soricomorphs and rodents we have information on few sites found up to 1980, mainly resulting from the analysis of the owls' diet (Pucek \& Raczyński 1983). Five species of soricomorphs and 11 species of rodents were then recorded, including a site of the northern birch mouse Sicista betulina (Pallas, 1778) near Karczew (Pucek 1983). Later, species composition of small mammals was studied in the nature reserves: Jan III Sobieski (Stolarz \& Lesiński 1998, Lesiński \& Stolarz 1999) and Bagno Jacka (Stolarz \& Lesiński 2012). One site of the common dormouse Muscardinus avellanarius (Linnaeus, 1758) in Ponurzyca (Lesiński \& Gryz 2008) and one of the northern birch mouse near Okuniew (Lesiński et al. 1998) were also found. Several papers and notes published so far on bats have reported on seven species (Lesiński \& Stolarz 1999, Lesiński et al. 2008, Lesiński 2009, Lesiński et al. 2009, 2010, 2011).

The aim of the presented study was to supplement data on species composition and domination structure of small mammal communities through the analysis of the diet of 
common owl species. This method allows for obtaining abundant data in relatively short time and is often used in description of mammal communities (Gryz \& Krauze 2007, Żmihorski et al. 2011, Heisler et al. 2016). Hunting in owls (especially tawny owls) is largely opportunistic and the frequency of caught prey depends on their availability. The share of small mammals (especially dominating species) in the diet of tawny owls reflects properly the proportion of their number in the hunting grounds of these predators (Balčiauskienè \& Naruševičius 2006). In our study we expected that in northern part of the study area situated at the outskirts of Warsaw agglomeration, mammal communities would show species impoverishment comparing to southern part.

\section{STUDY AREA, MATERIAL AND METHODS}

A study was carried out in Czesław Łaszek Masovian Landscape Park situated south-east of Warsaw and in adjacent areas within $11 \mathrm{~km}$ from the park. The area has a large forest cover. Built-up areas are common in northern part of the park (Fig. 1).

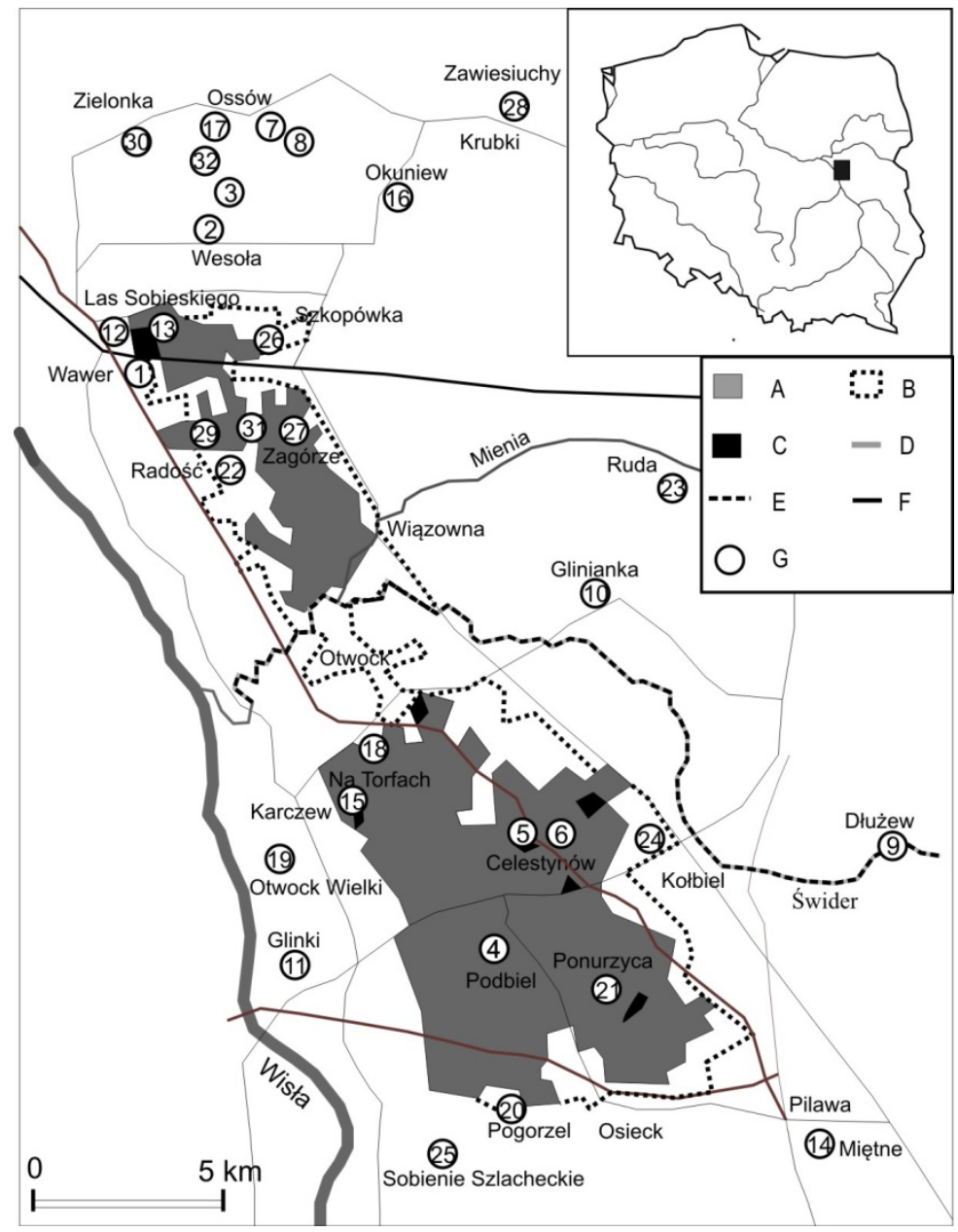

Fig. 1. Distribution of sites where owls' pellets were collected. A - the Masovian Landscape Park, B - borders of protection zone of the park, C - nature reserves, D - rivers, E - the Świder reserve, F - roads and railways, G - study sites. 
The Masovian Landscape Park was established in the years 1986-1987. It occupies an area of 15,710 ha; its buffer zone covers additional 7,992 ha. In agreement with foundation statute its aim is to protect nature, to popularize biological, historical and cultural values and to support educational activity. The park encompasses belts of sandy dunes cut by peatlands typical of large parts of Mid-Poland Lowlands. Rainfall-fed raised peatbogs and transitional moors are frequent there. The largest areas of the park are covered, however, by lowland bogs, which form the so-called „Bagno Całowanie” - one of the largest bogs in Masovia (now including two areas Natura 2000). The park is overgrown by forests in more than $75 \%$. These are mainly coniferous forests dominated by pine Pinus sylvestris L. with local admixtures of birch Betula pendula Roth and oak Quercus spp. Land depressions are occupied by wet deciduous forests - alder woods, riparian forests and wet coniferous forests. Most valuable parts of the park are protected in a form of nine nature reserves. Moreover, there are four Natura 2000 areas and 42 lands of ecological use within the park's borders.

Northward, the park neighbours Rembertów-Okuniew Forests. This is a forest-dunepeatbog area situated on Wołomin Plain on sands underlined by boulder loams that outcrop in valleys of the Długa and Czarna Rivers. Being used as a military training ground for over 120 years, the area is underpopulated. The Vistula River valley is spread south-west and west of the park. Agricultural lands on silty alluvial (less frequently on sandy) soils with scarce dunes dominate there. Small areas are occupied by forests in riparian habitat and, at higher elevations - coniferous forests. The valley is characterised by the presence of oxbow lakes of the Vistula at various stages of overgrowing. Densely forested south-eastern parts of the study area are situated on Garwolin Plain (a sandy-loamy postglacial plain) and farther to the east there are agricultural lands with a small percent of forests. To the north-west, the park borders intensively urbanised grounds of Warsaw.

The diet of owls was studied by analyzing pellets dropped in 32 sites by three species: the tawny owl Strix aluco Linnaeus, 1758 - 26 sites, barn owl Tyto alba (Scopoli, 1769) - 1 site and long-eared owl Asio otus (Linnaeus, 1758) - 5 sites. Seventeen sites of owls were found in the Masovian Landscape Park and in grounds localised within $1 \mathrm{~km}$ from its borders. Study material was collected in the years 1993-2016 (Table 1). The following subunits were distinguished to compare mammal communities in various parts of the study area: (1) northern part of the Masovian Landscape Park south to the Świder River (sites: 1, 12, 13, 22, 26, 27, 29 , 31), (2) southern part of the Masovian Landscape Park (sites: 4, 5, 6, 15, 18, 20, 21, 24), (3) areas between Rembertów and Okuniew (sites: 2, 3, 7, 8, 16, 17, 30, 32) and (4) other areas around the park (sites: 9, 10, 11, 14, 19, 23, 25, 28).

Pellets were prepared after soaking them in water. Prey species were determined based mainly of the features of their skulls and only in a few cases - based on other bones (arm bones of mole Talpa europaea Linnaeus, 1758). When determining the species of mammals, the key edited by Pucek (1984), specific publication by Ruprecht (1987) on the determination of bat mandibles and a comparative collection were used. Birds were identified mostly by skulls (rarely arm bones), amphibians by pelvic bones, reptiles and fishes by teeth or scales.

Study material contained 5,728 individuals of vertebrates including 4,001 individuals of mammals. Unpublished data were combined with data published earlier on the diet of the tawny owl in two nature reserves: Sobieski Forest (268 vertebrates incl. 191 mammals Lesiński \& Stolarz 1999) and Bagno Jacka (462 vertebrates incl. 245 mammals - Stolarz \& Lesiński 2012) and on three particular species: the northern birch mouse (site Długa II Lesiński et al. 1998), the common dormouse (site Ponurzyca - Lesiński \& Gryz 2008) and on bats (sites Ponurzyca, Zawiesiuchy, Zielonka - Lesiński 2009). Most data on mammals were obtained from the analysis of diet of the tawny owl - 3,744 individuals, much less from the diet of the long-eared owl - 194 individuals and the least - from that of the barn owl - 63 
individuals. Other groups of vertebrates were less frequently represented in the diet of owls. In pellets dropped by the tawny owl birds were represented by 603 individuals, reptiles by 3, amphibians by 1,133 and fish - by 1 . In pellets of the long-eared owl birds were represented by 6 and in the diet of the barn owl - by 1 individual.

Frequencies of the numbers of individuals belonging to pairs of species caught by owls were compared by $\chi^{2}$ test with Yates correction using 2 × 2 tables. Calculations were performed with the Statistica 10 software.

Table 1. The list and characteristics of study sites in the Masovian Landscape Park and its surrounding, study periods; MLP - Masovian Landscape Park, Sa - Strix aluco, Ao - Asio otus, Ta - Tyto alba.

\begin{tabular}{|c|c|c|c|}
\hline Site, owl species & Habitat type & $\begin{array}{c}\text { Place of pellet } \\
\text { collection }\end{array}$ & Years \\
\hline 1. Anin, $S a$ & $\begin{array}{l}\text { Settlement } 300 \mathrm{~m} \text { from the MLP borderline, } \\
\text { high-density housing in some places. }\end{array}$ & building & 2014 \\
\hline 2. Bagno Jacka, $S a$ & $\begin{array}{l}\text { Mixed forest and peatbog } 1.5 \mathrm{~km} \text { north of the } \\
\text { MLP borderline. Nature reserve of an area of } \\
19.76 \text { ha was established there. }\end{array}$ & $\begin{array}{l}\text { under a nesting } \\
\text { box and trees }\end{array}$ & $\begin{array}{l}2011-2012 \\
2013-2016\end{array}$ \\
\hline 3. Bagno Śmiardki, Sa & $\begin{array}{l}\text { Mid-forest bog near sewage tanks } 2 \mathrm{~km} \text { north of } \\
\text { the MLP. }\end{array}$ & under trees & 2013-2016 \\
\hline 4. Całowanie (MLP), Ao & $\begin{array}{l}\text { Lowland peatbog (dried in some places). The } \\
\text { area is dominated by grasslands. Small woodlots } \\
\text { present on drier sites. }\end{array}$ & $\begin{array}{l}\text { under trees mainly } \\
\text { in pine woodlots }\end{array}$ & $\begin{array}{l}2006,2011- \\
2016\end{array}$ \\
\hline $\begin{array}{l}\text { 5. Celestynowski Grąd } \\
\text { (MLP), Sa }\end{array}$ & $\begin{array}{l}\text { Fragment of dry ground forest protected as } \\
\text { nature reserve. Up to } 100 \text { years old tree stand is } \\
\text { dominated by oaks and hornbeams. }\end{array}$ & under trees & 2016 \\
\hline $\begin{array}{l}\text { 6. Celestynów (MLP), } \\
\qquad S a\end{array}$ & $\begin{array}{l}\text { Border of forest and settlement with multi-storey } \\
\text { buildings. Mature tree stand dominated by pine } \\
\text { with well developed undergrowth. }\end{array}$ & $\begin{array}{l}\text { under hollow and } \\
\text { nearby trees }\end{array}$ & 2015-2016 \\
\hline $\begin{array}{l}\text { 7. Długa I (Forestry } \\
\text { Commission } \\
\text { Drewnica unit 23), Sa }\end{array}$ & $\begin{array}{l}\text { Forests adjacent to the Długa River valley, about } \\
8 \mathrm{~km} \text { from the MLP border. }\end{array}$ & under trees & 1997 \\
\hline $\begin{array}{l}\text { 8. Długa II (Forestry } \\
\text { Commission } \\
\text { Drewnica unit 68), Sa }\end{array}$ & $\begin{array}{l}\text { North-east part of Rembertów-Okuniew Forests, } \\
\text { about } 7 \mathrm{~km} \text { from the MLP border. }\end{array}$ & under trees & 1997, 1999 \\
\hline 9. Dłużew, Sa & $\begin{array}{l}\text { Over } 100 \text {-year-old park in oak-hornbeam habitat } \\
\text { with planted coniferous trees surrounded by wet } \\
\text { and fresh meadows in the Świder River valley, } 6 \\
\text { km east of the MLP. }\end{array}$ & under trees & 2015-2016 \\
\hline 10. Glinianka, $S a$ & $\begin{array}{l}\text { Old park between village and Świder nature } \\
\text { reserve } 5 \mathrm{~km} \text { from the MLP border. }\end{array}$ & under trees & 2015-2016 \\
\hline 11. Glinki, Sa & $\begin{array}{l}\text { Old park in oak-hornbeam habitat surrounded by } \\
\text { fields, } 4 \mathrm{~km} \text { west of the MLP. }\end{array}$ & under trees & 2016 \\
\hline 12. Las Matki Mojej, Ao & $\begin{array}{l}\text { Small forest complex } 700 \mathrm{~m} \text { from the western } \\
\text { border of the MLP surrounded by dense housing, } \\
\text { unused railway and industrial grounds. }\end{array}$ & under trees & 2016 \\
\hline $\begin{array}{l}\text { 13. Las Sobieskiego } \\
\text { (MLP), Sa }\end{array}$ & $\begin{array}{l}\text { Dense forests mainly in oak-hornbeam and } \\
\text { mixed forest habitats. Forest reserve of an area } \\
\text { of } 113.92 \text { ha established in western part. }\end{array}$ & under trees & $\begin{array}{l}\text { 1993-1996, } \\
2009-2016\end{array}$ \\
\hline 14. Miętne, Sa & $\begin{array}{l}\text { The manor park in the area of } 7.5 \text { ha, } 9 \mathrm{~km} \\
\text { south-east of the MLP. There are numerous old } \\
\text { trees and a water body. }\end{array}$ & under trees & 2016 \\
\hline 15. Na Torfach (MLP), Sa & $\begin{array}{l}\text { Nature reserve covering fragment of wet forests } \\
\text { and a water body. }\end{array}$ & $\begin{array}{l}\text { in nesting box and } \\
\text { under trees }\end{array}$ & 2005-2013 \\
\hline 16. Okuniew, Sa & $\begin{array}{l}\text { Remnants of an old park with palace ruins } \\
\text { adjacent to the village and the Dhuga River, } 6 \mathrm{~km} \\
\text { north-east of the MLP. }\end{array}$ & under trees & 2015-2016 \\
\hline 17. Ossów, Ao & $\begin{array}{l}\text { Pine forests near the Dhuga River valley, about } 8 \\
\mathrm{~km} \text { from the MLP border. }\end{array}$ & under trees & 2003 \\
\hline
\end{tabular}


Continuation of the Table 1

\begin{tabular}{|c|c|c|c|}
\hline Site, owl species & Habitat type & $\begin{array}{l}\text { Place of pellet } \\
\text { collection }\end{array}$ & Years \\
\hline 18. Otwock (MLP), Sa & $\begin{array}{l}\text { Buildings in forest. There is mature pine tree } \\
\text { stand with well developed undergrowth near } \\
\text { the site. }\end{array}$ & $\begin{array}{l}\text { buildings and } \\
\text { under trees }\end{array}$ & 2004-2015 \\
\hline 19. Otwock Wielki, Sa & $\begin{array}{l}\text { Park and an 18th century palace on island } \\
\text { situated in oak-hornbeam and riparian } \\
\text { habitats, } 4 \mathrm{~km} \text { west of the MLP borders. }\end{array}$ & under trees & 2015-2016 \\
\hline 20. Pogorzel Osiecka, $T a$ & $\begin{array}{l}\text { Village close to the MLP border. The village } \\
\text { is surrounded by agricultural lands on partly } \\
\text { drained peatland and by poor pine forests. }\end{array}$ & $\begin{array}{l}\text { attic and tower of } \\
\text { the church }\end{array}$ & 2012 \\
\hline 21. Ponurzyca (MLP), Sa & $\begin{array}{l}\text { Dispersed rural housing in a hilly area with } \\
\text { many garden plots. Nearby, rather young } \\
\text { forests dominated by pine trees. }\end{array}$ & barn & 2002 \\
\hline 22. Radość, Sa & $\begin{array}{l}\text { Settlement about } 50 \mathrm{~m} \text { from the MLP border } \\
\text { neighbouring forest and family housing. }\end{array}$ & $\begin{array}{l}\text { abandoned } \\
\text { building }\end{array}$ & 2015 \\
\hline $\begin{array}{l}\text { 23. Ruda near Dębe Wielkie, } \\
\qquad S a\end{array}$ & $\begin{array}{l}\text { Old park in oak-hornbeam habitat and mixed } \\
\text { forest in the Mienia River valley near } \\
\text { fishponds, } 8 \mathrm{~km} \text { east of the MLP border. }\end{array}$ & under trees & 2013-2016 \\
\hline 24. Skorupy, Ao & $\begin{array}{l}\text { Mid-field forest surrounded by pastures and } \\
\text { arable lands, } 1 \mathrm{~km} \text { east of the MLP. }\end{array}$ & under trees & 2016 \\
\hline 25. Sobienie Szlacheckie, Sa & $\begin{array}{l}\text { Old park with a palace used as a hotel } \\
\text { surrounded by fields and meadows, } 4 \mathrm{~km} \\
\text { south of the MLP. }\end{array}$ & under trees & 2016 \\
\hline 26. Stara Miłosna, Ao & $\begin{array}{l}\text { Hippodrome surrounded by pine tree stands, } \\
\text { about } 200 \mathrm{~m} \text { from the MLP border. }\end{array}$ & under trees & 2015 \\
\hline 27. Zagórze (MLP), Sa & $\begin{array}{l}\text { A junction of coniferous forest, oak- } \\
\text { hornbeam forest and alder wood near a } \\
\text { hospital. }\end{array}$ & under trees & 2014-2016 \\
\hline 28. Zawiesiuchy, Sa & $\begin{array}{l}\text { Complex of fishponds } 11 \mathrm{~km} \text { north-east of } \\
\text { the MLP. }\end{array}$ & nesting box & 2008 \\
\hline 29. Zbójna Góra (MLP), Sa & $\begin{array}{l}\text { Dense forest complex dominated by pine and } \\
\text { oaks. }\end{array}$ & under trees & 2015-2016 \\
\hline 30. Zielonka, Sa & $\begin{array}{l}\text { Buildings in forest, } 4 \mathrm{~km} \text { north of the MLP. } \\
\text { Forests with a great share of pine and birch } \\
\text { are cut by small wetlands. }\end{array}$ & unused buildings & 2002-2007 \\
\hline 31. Zielony Ług (MLP), Sa & $\begin{array}{l}\text { Peatland and overgrowing water bodies } \\
\text { surrounded by pine forests. }\end{array}$ & under trees & 2015-2016 \\
\hline 32. Złota Lipa, Sa & $\begin{array}{l}\text { Forests and wetlands, } 3 \mathrm{~km} \text { north of the } \\
\text { MLP. }\end{array}$ & under trees & 1995, 2016 \\
\hline
\end{tabular}

\section{RESULTS}

\section{Survey of species}

Twenty six species of small mammals were found in the diets comprised of total 4,001 individuals. Below there is general information about the frequency of their occurrence.

\section{Soricomorphs - Soricomorpha}

\section{European mole - Talpa europaea Linnaeus, 1758}

Not often caught by owls, found in 14 sites. It accounted for less than $1 \%$ of mammals in the diet of the tawny owl.

\section{Common shrew - Sorex araneus Linnaeus, 1758}

One of the most common species of mammals frequently caught by owls. Found in 24 sites. 
Pigmy shrew - Sorex minutus Linnaeus, 1766

The species caught less often than the common shrew. Found in the diet of the tawny owl and barn owl in 15 sites. Relatively great share of this species (over 10\%) was noted in Celestynów site.

$$
\text { Water shrew - Neomys fodiens (Pennant, 1771) }
$$

Rare species in the study area. There were only four sites of this species - one in the Świder River valley and three in wetland areas (peatland Całowanie and Rembertów-Okuniew Forests).

Bicoloured white-toothed shrew - Crocidura leucodon (Hermann, 1780)

The only site of this species was found in Dłużew at the eastern edge of the study area.

Bats - Chiroptera

$$
\text { Natterer's bat - Myotis nattereri (Kuhl, 1817) }
$$

Found in only one site in Rembertów-Okuniew Forests.

Daubenton's bat - Myotis daubentonii (Kuhl, 1817)

One site of this species was found in southern part of the Masovian Landscape Park.

Serotine bat - Eptesicus serotinus (Schreber, 1774)

Four individuals were found in three sites. The second numerous species among bats caught by owls.

Noctule bat - Nyctalus noctula (Schreber, 1774)

One individual was noted in each of two sites.

Nathusius’ bat - Pipistrellus nathusii (Keyserling et Blasius, 1839)

The only site of this species was noted in nature reserve Bagno Jacka in northern part of the study area.

$$
\text { Brown long-eared bat - Plecotus auritus (Linnaeus, 1758) }
$$

From among bats this species was most often caught by owls. Nine individuals were found in six sites.

Rodents - Rodentia

$$
\text { Bank vole - Myodes glareolus (Schreber, 1870) }
$$

Most common and definitely most frequent species of mammals in the diet of the tawny owl.

European pine vole - Microtus subterraneus (de Sélys-Longchamps, 1836) area.

It was present in the diet of the tawny owl but only in one site in northern part of the study

$$
\text { Common vole - Microtus arvalis (Pallas, 1779) }
$$

The species often caught by owls. Its share in the diet of the long-eared owl and barn owl was greater than in the diet of the tawny owl. Caught more often by tawny owls from sites situated outside the Masovian Landscape Park. 
Field vole - Microtus agrestis (Linnaeus, 1761)

Its presence was noted exclusively in the diet of tawny owls from three sites. Most individuals were caught in southern part of the Masovian Landscape Park.

Root vole - Microtus oeconomus (Pallas, 1776)

Quite often caught by owls but usually less frequently than the common vole. Only in peatland Całowanie this species was most numerous in the diet of the long-eared owl.

House mouse - Mus musculus Linnaeus, 1758

Frequent but not numerous component of the diet of the barn owl and tawny owl. Most often it was found in sites Anin and Okuniew.

Brown rat - Rattus norvegicus (Berkenhout, 1769)

Not often caught by owls, noted in 10 sites.

Striped field mouse - Apodemus agrarius (Pallas, 1771)

Caught by owls rather frequently. From among mammals its greatest share (14.2\%) was noted in northern part of the Masovian Landscape Park.

Wood mouse - Apodemus sylvaticus (Linnaeus, 1758)

Nine sites were found of this species, which was not very numerous in the diet of the barn owl and tawny owl.

Yellow-necked mouse - Apodemus flavicollis (Melchior, 1834)

This species was found exclusively in the diet of the tawny owl. In all parts of the study area it was most frequent and numerous prey among mammals.

Harvest mouse - Micromys minutus (Pallas, 1771)

Found in 17 sites but usually constituted a small percent of mammals caught by the three owl species.

\section{Common dormouse - Muscardinus avellanarius (Linnaeus, 1758)}

This species was found in three sites situated in southern part of the Masovian Landscape Park. Its mean share in the diet of the tawny owl from this area was $2.9 \%$.

Northern birch mouse - Sicista betulina Pallas, 1779

Only one site of this species was found in eastern part of Rembertów-Okuniew Forests.

Red squirrel - Sciurus vulgaris Linnaeus, 1758

The species rarely caught by owls. It was present in the diet of the tawny owls in two sites.

Carnivores - Carnivora

$$
\text { Weasel - Mustela nivalis Linnaeus, } 1766
$$

Found in the diet of the long-eared owl in one site near south-eastern borders of the Masovian Landscape Park. 


\section{Characteristics of mammal communities in various parts of the study area}

Differences in species composition and proportions of particular prey species were found in the diet of the tawny owl among various parts of the study area. Typically forest species as the bank vole and yellow-necked mouse (46.2\% by total number of mammals) dominated in northern part of the Masovian Landscape Park. The striped field mouse, however, had also a substantial share in the diet in this part (Table 2). This rodent species was not so frequently caught by tawny owls in other parts of the study area. The same species dominated in southern

Table 2. Small mammals in the diet of tawny owls in northern part of the Masovian Landscape Park.

\begin{tabular}{|c|c|c|c|c|c|c|c|}
\hline \multirow[t]{2}{*}{ No. Prey category } & $\begin{array}{c}\text { Las } \\
\text { Sobies- } \\
\text { kiego }\end{array}$ & Anin & Radość & $\begin{array}{l}\text { Zielony } \\
\text { Ług }\end{array}$ & Zagórze & $\begin{array}{c}\text { Zbójna } \\
\text { Góra }\end{array}$ & \multirow[t]{2}{*}{$\begin{array}{c}\text { Total } \\
\text { N (\%) }\end{array}$} \\
\hline & \multicolumn{6}{|c|}{$\mathrm{N}$} & \\
\hline 1. Talpa europaea & 2 & 4 & 1 & & & 2 & $9(1.2)$ \\
\hline 2. Sorex araneus & 53 & 1 & & 14 & 4 & 9 & $81(10.6)$ \\
\hline 3. S. minutus & 4 & & & 1 & 1 & & $6(0.8)$ \\
\hline 4. Nyctalus noctula & 1 & & & & & & $1(0.1)$ \\
\hline 5. Myodes glareolus & 135 & 2 & & 41 & 9 & 33 & 220 (28.9) \\
\hline 6. Microtus subterraneus & 4 & & & & & & $4(0.5)$ \\
\hline 7. M. arvalis & 4 & & & & & 1 & $5(0.7)$ \\
\hline 8. M. оесопотиs & & & & & 1 & & $1(0.1)$ \\
\hline 9. Microtus spp. & 2 & 1 & & 4 & & 3 & $10(1.3)$ \\
\hline 10. Mus musculus & 3 & 16 & 1 & & & 2 & $22(2.9)$ \\
\hline 11. Rattus norvegicus & 3 & 5 & & & & 1 & $9(1.2)$ \\
\hline 12. Apodemus agrarius & 53 & 26 & 6 & 4 & & 19 & $108(14.2)$ \\
\hline 13. A. sylvaticus & 7 & & & & & 1 & $8(1.0)$ \\
\hline 14. A. flavicollis & 44 & 4 & & 33 & 2 & 49 & 132 (17.3) \\
\hline 15. Apodemus spp. & 80 & 12 & 2 & 22 & 7 & 18 & $141(18.5)$ \\
\hline 16. Micromys minutus & 3 & & & & 1 & & $4(0.5)$ \\
\hline \multirow[t]{2}{*}{ 17. Rodentia indet. } & 1 & & & & & & $1(0.1)$ \\
\hline & 399 & 71 & 10 & 119 & 25 & 138 & $762(100.0)$ \\
\hline
\end{tabular}

Table 3. Small mammals in the diet of tawny owls in southern part of the Masovian Landscape Park; ${ }^{1}$ - mentioned by Lesiński (2009), ${ }^{2}$ - mentioned by Lesiński \& Gryz (2008).

\begin{tabular}{|c|c|c|c|c|c|c|}
\hline \multirow[t]{2}{*}{ No. Prey category } & Otwock & $\begin{array}{c}\mathrm{Na} \\
\text { Torfach }\end{array}$ & $\begin{array}{c}\text { Celesty- } \\
\text { nowski Grąd }\end{array}$ & Celestynów & Ponurzyca & \multirow[t]{2}{*}{$\begin{array}{l}\text { Total } \\
\text { N (\%) }\end{array}$} \\
\hline & \multicolumn{5}{|c|}{$\mathrm{N}$} & \\
\hline 1. Talpa europaea & 1 & & & 1 & 2 & $4(0.6)$ \\
\hline 2. Sorex araneus & 26 & 1 & 1 & 42 & 17 & $87(12.8)$ \\
\hline 3. S. minutus & 2 & 1 & & 29 & 2 & $34(5.0)$ \\
\hline 4. Myotis daubentonii & & & & & $1^{1}$ & $1(0.1)$ \\
\hline 5. Plecotus auritus & & & & 1 & $1^{1}$ & $2(0.3)$ \\
\hline 6. Myodes glareolus & 35 & 20 & & 63 & 41 & 159 (23.3) \\
\hline 7. Microtus arvalis & 1 & 6 & & 13 & 40 & $60(8.8)$ \\
\hline 8. M. oеconomus & 2 & 2 & & 7 & 7 & $18(2.6)$ \\
\hline 9. M. agrestis & & & & 30 & 3 & $33(4.8)$ \\
\hline 10. Microtus spp. & & 2 & & 4 & 1 & $7(1.0)$ \\
\hline 11. Mus musculus & 2 & & & 3 & 13 & $18(2.6)$ \\
\hline 12. Rattus norvegicus & 4 & & & & 1 & $5(0.7)$ \\
\hline 13. Apodemus agrarius & 11 & 10 & & & 4 & $25(3.7)$ \\
\hline 14. A. sylvaticus & 1 & & & & 9 & $10(1.5)$ \\
\hline 15. A. flavicollis & 37 & 15 & & 18 & 8 & $78(11.4)$ \\
\hline 16. Apodemus spp. & 16 & 22 & & 18 & 43 & $99(14.5)$ \\
\hline 17. Micromys minutus & 10 & 8 & & 5 & & $23(3.4)$ \\
\hline 18. Muscardinus avellanarius & 4 & & & 9 & $5^{2}$ & $18(2.6)$ \\
\hline 19. Rodentia indet. & & 1 & & & & $1(0.1)$ \\
\hline Total & 152 & 88 & 1 & 243 & 198 & $682(100.0)$ \\
\hline
\end{tabular}


part of the park. The share of voles Microtus spp. however, increased there compared with northern part of the study area. The common dormouse and field vole were noted only in southern part (Table 3). Comparison of frequenciess of individuals of particular species showed significant differences among various parts of the Masovian Landscape Park in the following species: the bank vole, striped field mouse and yellow-necked mouse (more frequent in the north) and the pigmy shrew, common vole, field vole, root vole, harvest mouse and common dormouse (more frequent in the south) (Table 4).

Table 4. Comparison of frequencies of selected prey species (groups) in the diet of the tawny owl between northern and southern parts of the Masovian Landscape Park. Numbers of individuals of a given species (group) are presented in relation to the number of individuals of remaining mammal species.

\begin{tabular}{rlrll}
\hline No. & \multicolumn{1}{c}{ Prey } & North part & South part & \multicolumn{1}{c}{ Difference $\left(\chi^{2}, \mathrm{p}\right)$} \\
\hline 1. & Talpa europaea & $9: 753$ & $4: 578$ & $0.4, \mathrm{p}=0.52, \mathrm{NS}$ \\
2. & Sorex araneus & $81: 681$ & $87: 595$ & $1.4, \mathrm{p}=0.24, \mathrm{NS}$ \\
3. & S. minutus & $6: 756$ & $34: 648$ & $22.0, \mathrm{p}<0.001$ \\
4. & Chiroptera & $1: 761$ & $3: 679$ & $0.4, \mathrm{p}=0.54$, NS \\
5. & Myodes glareolus & $220: 542$ & $159: 523$ & $5.5, \mathrm{p}<0.05$ \\
6. & Microtus arvalis & $5: 757$ & $60: 622$ & $15.6, \mathrm{p}<0.001$ \\
7. & M. oeconomus & $1: 761$ & $18: 664$ & $15.5, \mathrm{p}<0.001$ \\
8. & M. agrestis & $0: 762$ & $33: 649$ & $35.6, \mathrm{p}<0.001$ \\
9. & Mus musculus & $22: 740$ & $18: 664$ & $0.0, \mathrm{p}=0.90, \mathrm{NS}$ \\
10. & Rattus norvegicus & $9: 753$ & $5: 677$ & $0.4, \mathrm{p}=0.55, \mathrm{NS}$ \\
11. & Apodemus agrarius & $108: 654$ & $25: 657$ & $46.3, \mathrm{p}<0.001$ \\
12. & A. flavicollis & $132: 630$ & $78: 604$ & $9.6 \mathrm{p}<0.001$ \\
13. & Micromys minutus & $4: 758$ & $23: 659$ & $14.3, \mathrm{p}<0.001$ \\
14. & Muscardinus avellanarius & $0: 762$ & $18: 664$ & $18.4, \mathrm{p}<0.001$ \\
\hline
\end{tabular}

Table 5. Species composition and the frequency of catching mammals by tawny owls in areas between Rembertów and Okuniew; ${ }^{1}$ mentioned by Lesiński (2009), ${ }^{2}$ mentioned by Lesiński et al. (1998)

\begin{tabular}{|c|c|c|c|c|c|c|c|c|c|}
\hline \multirow[t]{2}{*}{ No. } & \multirow[t]{2}{*}{ Prey category } & $\begin{array}{c}\text { Zie- } \\
\text { lonka }\end{array}$ & $\begin{array}{r}\text { Bagno } \\
\text { Jacka }\end{array}$ & $\begin{array}{c}\text { Bagno } \\
\text { Śmiardki }\end{array}$ & $\begin{array}{c}\text { Złota } \\
\text { Lipa }\end{array}$ & Długa I & Długa II & Okuniew & \multirow{2}{*}{$\begin{array}{c}\text { Total } \\
\text { N (\%) }\end{array}$} \\
\hline & & \multicolumn{7}{|c|}{ 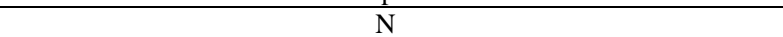 } & \\
\hline & Talpa europaea & 2 & 2 & & & 3 & & 2 & $9(0.5)$ \\
\hline 2. & Sorex araneus & 37 & 78 & 2 & 6 & 10 & 5 & 2 & $140(7.6)$ \\
\hline & S. minutus & 19 & 10 & & 2 & & 7 & & $38(2.0)$ \\
\hline & Neomys fodiens & & & 4 & 1 & & & & $5(0.3)$ \\
\hline & Myotis nattereri & $1^{1}$ & & & & & & & $1(0.1)$ \\
\hline & Eptesicus serotinus & $2^{1}$ & & & & & & & $2(0.1)$ \\
\hline & Pipistrellus nathusii & & 1 & & & & & & $1(0.1)$ \\
\hline & Nyctalus noctula & & 1 & & & & & & $1(0.1)$ \\
\hline 9. & Plecotus auritus & $4^{1}$ & 1 & & & & & & $5(0.3)$ \\
\hline 10. & Myodes glareolus & 231 & 121 & 30 & 8 & 38 & 47 & 6 & 481 (25.9) \\
\hline 11. & Microtus arvalis & 48 & 75 & 4 & 6 & 8 & & 3 & 144 (7.8) \\
\hline 12. & M. oeconomus & 1 & 30 & 3 & 14 & 3 & 5 & 1 & $57(3.1)$ \\
\hline 13. & M. agrestis & & 1 & & & & & & $1(0.1)$ \\
\hline 14. & Microtus spp. & & 10 & & & 1 & 2 & 3 & $16(0.9)$ \\
\hline 15. & Mus musculus & 3 & 4 & 1 & & 2 & & 12 & $22(1.2)$ \\
\hline 16. & Rattus norvegicus & 11 & 3 & & & & & 5 & $19(1.0)$ \\
\hline 17. & Rattus spp. & 6 & 1 & & 1 & 1 & & & $9(0.5)$ \\
\hline 18. & Apodemus agrarius & 38 & 48 & 9 & 1 & 3 & 2 & 5 & $106(5.7)$ \\
\hline 19. & A. sylvaticus & 44 & 8 & 1 & 1 & & 2 & & $56(3.0)$ \\
\hline 20. & A. flavicollis & 53 & 158 & 7 & 7 & 3 & 2 & & $230(12.4)$ \\
\hline 21. & Apodemus spp. & 215 & 163 & 23 & 14 & 10 & 3 & 5 & 433 (23.4) \\
\hline 22. & Micromys minutus & 37 & 16 & 7 & & 4 & 4 & 3 & $71(3.8)$ \\
\hline 23. & Sicista betulina & & & & & & $4^{2}$ & & $4(0.2)$ \\
\hline 24. & Sciurus vulgaris & 2 & & & & & & & $2(0.1)$ \\
\hline 25. & Rodentia indet. & & 1 & & & & & & $1(0.1)$ \\
\hline & Total & 754 & 732 & 91 & 61 & 86 & 83 & 47 & $1,854(100.0)$ \\
\hline
\end{tabular}


The bank vole and yellow-necked mouse dominated in mammal communities in densely forested or partly wet grounds between Rembertów and Okuniew. The northern birch mouse was present only there. The highest number of bat species (5) was noted in two sites. Substantial share of synanthropic species (the house mouse and brown rat) was found in site Okuniew situated in a village park (Table 5).

Table 6. Species composition and the frequency of catching mammals by tawny owls in the remaining sites around the Masovian Landscape Park; ${ }^{1}$ mentioned by Lesiński (2009).

\begin{tabular}{|c|c|c|c|c|c|c|c|c|c|}
\hline \multirow[t]{2}{*}{ Prey category } & Dłużew & $\begin{array}{l}\text { Zawie- } \\
\text { siuchy }\end{array}$ & $\begin{array}{c}\text { Gli- } \\
\text { nianka }\end{array}$ & $\begin{array}{l}\text { Ruda k. } \\
\text { Dębego }\end{array}$ & Miętne & $\begin{array}{c}\text { Sobienie } \\
\text { Szla- } \\
\text { checkie }\end{array}$ & Glinki & $\begin{array}{l}\text { Otwock } \\
\text { Wielki }\end{array}$ & \multirow[t]{2}{*}{$\begin{array}{l}\text { Total } \\
\text { N (\%) }\end{array}$} \\
\hline & \multicolumn{8}{|c|}{$\mathrm{N}$} & \\
\hline 1. Talpa europaea & 3 & & & & & & & & $3(0.7)$ \\
\hline 2. Sorex araneus & 10 & 12 & & 12 & & 6 & & & 40 (9.0) \\
\hline 3. S. minutus & 1 & 1 & & 4 & & & & & $6(1.3)$ \\
\hline 4. Neomys fodiens & 1 & & & & & & & & $1(0.2)$ \\
\hline 5. Crocidura leucodon & 2 & & & & & & & & $2(0.4)$ \\
\hline 6. Eptesicus serotinus & 1 & $1^{1}$ & & & & & & & $2(0.4)$ \\
\hline 7. Plecotus auritus & 1 & & & 1 & & & & & $2(0.4)$ \\
\hline 8. Myodes glareolus & 40 & 3 & 1 & 94 & & 10 & & 1 & 149 (33.4) \\
\hline 9. Microtus arvalis & 37 & 4 & & 2 & 2 & 10 & 3 & 5 & $63(14.1)$ \\
\hline 10. M. оесопотиs & 24 & 6 & & 3 & & 3 & & 4 & $40(9.0)$ \\
\hline 11. Microtus spp. & 1 & 2 & & & & 1 & & 1 & $5(1.1)$ \\
\hline 12. Mus musculus & 3 & & & 3 & 1 & 1 & & & $8(1.8)$ \\
\hline 13. Rattus norvegicus & 2 & 2 & & & & & & & $4(0.9)$ \\
\hline 14. Rattus spp. & 1 & & & & & & 1 & & $2(0.4)$ \\
\hline 15. Apodemus agrarius & 6 & 1 & & 2 & & 8 & & 2 & 19 (4.3) \\
\hline 16. A. sylvaticus & & & & & & 6 & & & $6(1.3)$ \\
\hline 17. A. flavicollis & 7 & & 1 & 7 & & 6 & & 1 & 22 (4.9) \\
\hline 18. Apodemus spp. & 22 & & & 18 & & 6 & 3 & 1 & $50(11.2)$ \\
\hline 19. Micromys minutus & 6 & & & 7 & & 6 & & 1 & $20(4.5)$ \\
\hline 20. Sciurus vulgaris & 1 & & & & & & & & $1(0.2)$ \\
\hline 21. Rodentia indet. & & & 1 & & & & & & $1(0.2)$ \\
\hline Total & 169 & 32 & 3 & 153 & 3 & 63 & 7 & 16 & $446(100.0)$ \\
\hline
\end{tabular}

Table 7. Species composition and the frequency of catching mammals by long-eared owls and barn owls in the Masovian Landscape Park and in adjacent areas.

\begin{tabular}{|c|c|c|c|c|c|c|c|c|}
\hline \multirow[t]{2}{*}{ No. } & \multirow[t]{2}{*}{ Prey category } & $\begin{array}{c}\text { Las Matki } \\
\text { Mojej }\end{array}$ & $\begin{array}{c}\text { Stara } \\
\text { Miłosna }\end{array}$ & Całowanie & Skorupy & Ossów & $\begin{array}{c}\text { Pogorzel } \\
\text { Osiecka }\end{array}$ & \multirow[t]{2}{*}{$\begin{array}{c}\text { Total } \\
\text { N (\%) }\end{array}$} \\
\hline & & \multicolumn{6}{|c|}{$\mathrm{N}$} & \\
\hline 1. & Talpa europaea & & & 3 & 1 & & & $4(1.6)$ \\
\hline 2. & Sorex araneus & & & 4 & 1 & & 27 & 32 (12.5) \\
\hline 3. & S. minutus & & & & & & 2 & $2(0.8)$ \\
\hline 4. & Neomys fodiens & & & & & & 1 & $1(0.4)$ \\
\hline 5. & Myodes glareolus & & & & & 2 & & $2(0.8)$ \\
\hline 6. & Microtus arvalis & 19 & 12 & 11 & 5 & 48 & 13 & $108(42.0)$ \\
\hline 7. & M. oеconomus & & & 37 & & 3 & 10 & 50 (19.5) \\
\hline 8. & Microtus spp. & 10 & 8 & 10 & & & & 28 (10.9) \\
\hline 9. & Mus musculus & & & & & & 6 & $6(2.3)$ \\
\hline 10. & Apodemus agrarius & 1 & 1 & 4 & & & 2 & $8(3.1)$ \\
\hline 11. & A. sylvaticus & & & & & & 1 & $1(0.4)$ \\
\hline 12. & Apodemus spp. & 1 & 2 & 1 & & 1 & & 5 (1.9) \\
\hline 13. & Micromys minutus & & & 4 & & & 1 & 5 (1.9) \\
\hline 14. & Mustela nivalis & & & & 1 & & & $1(0.4)$ \\
\hline 15. & Rodentia indet. & 1 & 1 & 2 & & & & $4(1.6)$ \\
\hline & Total & 32 & 24 & 76 & 8 & 54 & 63 & $257(100.0)$ \\
\hline
\end{tabular}


Apart from species associated with woodlots and forests, species typical for open areas of fields and meadows were frequent among small mammals in grounds situated east, south and west of the Masovian Landscape Park (Table 6). The first group was dominated by the bank vole (about $1 / 3$ of all mammals being prey of tawny owls) and the second - by the common vole and root vole (nearly $1 / 5$ of all mammals). Most synanthropic rodent species (the bicoloured white-toothed shrew, the house mouse and brown rat) constituted $3.5 \%$ of small mammal prey.

The diet of the long-eared owl and barn owl was dominated by small mammals typical for open areas. The long-eared owl caught voles, chiefly the common vole. Only in site Całowanie the root vole was evidently more frequent. The barn owl caught common shrews more often. The house mouse appeared also in its diet but was absent from the diet of the long-eared owl (Table 7).

\section{DISCUSSION}

The majority of species of small mammals noted in the study area were well within their ranges. Only two of them (the northern birch mouse and bicolored white-toothed shrew) reached the borders of their ranges there. The site Długa II of the northern birch mouse, already described earlier (Lesiński et al. 1998), determines the western border of its range in this part of Poland. Finding the bicoloured white-toothed shrew in Dłużew supplements our knowledge on its distribution in Masovia. Western border of its range runs just there (Pucek \& Michalak 1983, Rychlik 2016) and this new site establishes this border.

Comparison with other forest complexes, like Kampinos Forest (Lesiński et al. 2013) and Chojnowski Landscape Park (Romanowski et al. 2014), studied with the same method reveals differences in the presence of some species and their share in communities. The water vole Arvicola amphibius (Linnaeus, 1758) was not found in our study area. However, this species was noted locally in few sites of Masovia, for example in Kampinos Forest, in Kozienice Forest, at the southern outskirts of Warsaw agglomeration or in the east of Masovia (Gryz et al. 2008, Lesiński et al. 2013, Zub 2016). The water shrew, field vole and common dormouse are more frequent in Kampinos Forest than in the Masovian Landscape Park and its surroundings while the share of the bank vole is a bit higher in the Chojnowski Landscape Park.

The presence of the northern birch mouse has not been recently confirmed in the Masovian Landscape Park (the last record was in site Karczew - Pucek 1983) but a new site was found in Rembertów-Okuniew Forests (Lesiński et al. 1998). We had too small sample of tawny owl's prey to certainly exclude the presence of at least small population in nature reserve Na Torfach near Karczew, where potential habitats of this species still exist. One may also assume that local population could remain in other parts of the Masovian Landscape Park, which is confirmed by the finding in Życzyn near Dęblin (Lesiński \& Gryz 2008). This site is about 40 $\mathrm{km}$ south-east of the park's border.

With respect to the number of soricomorphs and rodents found in the diet of owls, the Masovian Landscape Park with its surroundings stands out from other large Masovian areas studied so far. We found 19 species compared with 18 species in Kampinos Forest (Lesiński et al. 2013), 15 in Warsaw agglomeration (data from the recent years - Gryz et al. 2008, Lesiński \& Gryz 2012, Stolarz \& Lesiński 2012), or 12 species in the Chojnowski Landscape Park (Romanowski et al. 2014).

Relative abundance of the striped field mouse in the diet of the tawny owl in northern part of the Masovian Landscape Park is probably a result of remarkable transformation of forest habitats, which neighbour or interpenetrate urban areas. The phenomenon is similar to that describing the situation in woodlots of Warsaw agglomeration, where the striped field mouse 
definitely dominates the communities of small mammals (Andrzejewski et al. 1978, Gryz et al. 2008, Gortat et al. 2014, Krauze-Gryz et al. 2016).

Bats are rarely caught by owls. Their share in the diet of the long-eared owl, barn owl and tawny owl in our country usually does not exceed 1\% of vertebrate prey (Ruprecht 1979, Kowalski \& Lesiński 2002, Lesiński et al. 2009). Therefore, in a sample of 17 individuals of these animals one cannot find all species living in a given area. Recent chiropterological studies performed in Masovia (Kowalski \& Lesiński 1995, Lesiński et al. 2001, Kowalski et al. 2002, Lesiński 2003, Lesiński et al. 2006, 2011a, 2011b) indicate that the presence of other species of bats is possible in the study area. Bats found in the diet of owls belong to common and numerous species in this region of Poland. Noteworthy is frequent presence of the brown long-eared bat - a eurytopic species that inhabits both forests and agricultural lands (Lesiński 2006). It seems that this species better tolerates tree stands dominated by pine forests, which are common in the Masovian Landscape Park and its surroundings. The share of bats in mammals caught by tawny owls was slightly lower (0.5\%) than in Kampinos Forest $(0.8 \%$ Lesiński et al. 2013).

Results of this study indicate that the Masovian Landscape Park with its surrounding is an important sanctuary of small mammals in this region. Worth noting is the presence of species such as the bicoloured white-toothed shrew, northern birch mouse, common dormouse, field vole and water shrew. Of specific interest in the regional scale is probably numerous population of the root vole in peatland Całowanie. Continuation of studies in less recognised parts of the Masovian Landscape Park may bring the finding of new sites of some valuable species of small mammals, particularly those associated with wetlands.

\section{ACKNOWLEDGEMENTS}

Authors are grateful to Marek Blicharski, Paweł Kobyłecki, Janusz Kopik, Małgorzta Małolepszy, Wojciech Małolepszy, Waldemar Merecz, Marcin Sielecki, Marcin Tylutki and Kamil Żołądek for help in collecting study material, and two reviewers for valuable comments.

\section{REFERENCES}

ANDRZEJEWSKI R., BABIŃSKA-WERKA J., GLIWICZ J. \& GOSZCZYŃSKI J. 1978. Synurbization processes in population of Apodemus agrarius. I. Characteristics of populations in an urbanization gradient. Acta Theriologica 23: 341-358.

BALČIAUSKIENĖ L. \& NARUŠEVIČIUS V. 2006. Coincidence of small mammal trapping data with their share in the Tawny Owl diet. Acta Zoologica Lituanica 16: 93-101.

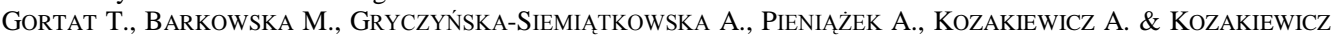
M. 2014. The effect of urbanization - small mammal communities in a gradient of human pressure in Warsaw city, Poland. Polish Journal of Ecology 62: 163-172.

GRYZ J. \& KRAUZE D. 2007. Analysis of owl pellets as a noninvasive method of finding rare species of mammals. Studia i Materiały Centrum Edukacji Przyrodniczo-Leśnej 9: 431-437. [in Polish with English summary]

GRYZ J., KRAUZE D. \& GOSZCZYŃSKi J. 2008. The small mammals of Warsaw as based on the analysis of tawny owl (Strix aluco) pellets. Annales Zoologici Fennici 45: 281-285.

HeISLER L. M., SOMERS C. M. \& POULIN R. G. 2016. Owl pellets: a more effective alternative to conventional trapping for broad-scale studies of small mammal communities. Methods in Ecology and Evolution 7: 96-103.

KOWALSKI M. \& LESIŃSKI G. 1995. Species composition and shelter preference of bats in the Kampinos Forest. Przegląd Przyrodniczy 6, 2: 99-108. [in Polish with English summary]

KOWALSKI M., KRASNODĘBSKI I. \& LESIŃSKI G. 2002. Winter monitoring of bat numbers in the large underground roosts in Warsaw in the period 1987 to 1999. Nietoperze 3: 101-107. [in Polish with English summary]

KOWALSKI M. \& LeSIŃSKI G. 2002. Bats in owl's diet on the Mazovia and Podlasie Lowlands. Nietoperze 3: $255-261$. [in Polish with English summary]

Krauze-Gryz D., Lesiński G., PieniążeK A., Romanowski J., Owsianka M. \& Prus M. 2016. Mammals of Skaryszewski Park in Warsaw. In: Romanowski J. (ed.), Skaryszewski Park in Warsaw - nature and use, Wydawnictwo UKSW, Warszawa: 215-226. [in Polish]

LEsiŃSKi G. 2003. Nietoperze. In: ANDRZEJEWSKi R. (ed.) Kampinos National Park, Kampinoski Park Narodowy, Izabelin, vol. 1: 647-654. [in Polish] 
LESIŃSKI G. 2006. The influence of anthropogenic changes in the landscape on the structure and functioning of bat ensembles. Wydaw. SGGW, Warszawa. [in Polish with English summary]

LESIŃSKI G. 2009. Localities of bats (Chiroptera) in Mazovia and Podlasie by analysis of the tawny owls' Strix aluco pellets. Nietoperze 10: 55-63. [in Polish with English summary]

LESIŃSKI G., BLICHARSKI M. \& SIELECKI M. 1998. The locality of the northern birch mouse (Sicista betulina) near Warsaw. Kulon 3: 101-103. [in Polish with English summary]

Lesiński G., Gulatowska J., Kowalski M., Fuszara E., Fuszara M. \& WoJTOwicz B. 2006. Bats of the Plonsk Plain. Nietoperze 7: 39-55. [in Polish with English summary]

LESIŃSKI G. \& GRYZ J. 2008. Localities of three rare mammal species in central and northeastern Poland. Fragmenta Faunistica 51: 63-69.

LESIŃSKI G. \& GRYZ J. 2012. How protecting a suburban forest as a natural reserve effected small mammal communities. Urban Ecosystems 15: 103-110.

LESIŃSKi G., GRYZ J. \& KowALSKi M. 2009. Bat predation by tawny owls Strix aluco in differently humantransformed habitats. Italian Journal of Zoology 76: 415-421.

LESIŃSKI G., JANIAK A. \& POPCZYK B. 2008. Examples of house cat predation on bats. Nietoperze 9: 236-238. [in Polish with English summary]

LesiŃSKi G., ŁePKOWSKA M., OLSZEWSKI A. \& SKRZYPIEC-NowAK P. 2010. Records of serotine bat Eptesicus serotinus in boxes in Kampinos National Park and Mazowiecki Landscape Park. Nietoperze 11: 50-52. [in Polish with English summary]

LESIŃSKI G., ŁEPKOWSKA M. \& SKRZYPIEC-NOWAK P. 2011a. Efficiency of bat boxes in Mazowiecki Landscape Park. Kulon 16: 75-82. [in Polish with English summary]

LEsiŃSKi G., OLSZEWSKI A. \& POPCZYK B. 2011b. Forest roads used by commuting and foraging bats in edge and interior zones. Polish Journal of Ecology 59: 611-616.

Lesiński G., Romanowski J., Gryz J., Olszewski A., Kowalski M., Krauze-Gryz D., Olech B., PePŁowsKaMARCZAK D. \& TARŁOWSKi A. 2013. Small mammals of Kampinos National Park and its protection zone, as revealed by analyses of the diet of tawny owls Strix aluco. Fragmenta Faunistica 56: 65-81.

LESIŃSKI G., SKRZYPIEC-NOWAK P., JANIAK A. \& JAGNIESZCZAK Z. 2009. Phenology of bat occurrence in boxes in central Poland. Mammalia 73: 33-37.

LESIŃSKI G. \& STOLARZ P. 1999. Vertebrates in the diet of the tawny owl Strix aluco in the Las Sobieskiego reserve in the outskirts of Warsaw. Kulon 1-2: 77-81. [in Polish with English summary]

PUCEK Z. \& MiCHALAK I. 1983. Crocidura leucodon (Hermann, 1780). In: PUCEK Z., \& RACZYŃSKi J. (eds), Atlas of Polish mammals. PWN, Warszawa: 60-61. [in Polish with English summary]

PUCEK Z. 1983. Sicista betulina (Pallas, 1778). In: PUCEK Z., \& RACZYŃSKI J. (eds), Atlas of Polish mammals. PWN, Warszawa: 132-134. [in Polish with English summary]

PuCEK Z. (ed.) 1984. Key to Polish mammals. PWN, Warszawa. [in Polish]

PUCEK Z. \& RACZYŃSKI J. (eds). 1983. Atlas of Polish mammals. PWN, Warszawa. [in Polish with English summary]

RomANOWSKi J., TARŁowsKi A., LesiŃSKi G. \& OlsZEWSKi A. 2014. Small mammals of Chojnowski Landscape Park in the diet of the tawny owl Strix aluco. Chrońmy Przyrodę Ojczystą 70: 63-67. [in Polish with English summary]

RupreCHT A. L. 1979. Bats (Chiroptera) as constituents of the food of barn owls Tyto alba in Poland. Ibis 121: 489-494.

RupRECHT A. L. 1987. A key for mandible identification of Polish bats. Przegląd Zoologiczny 31: 89-105. [in Polish with English summary]

RYCHLIK L. 2016. White-toothed shrew Crocidura leucodon (Hermann, 1780). Atlas of Polish mammals. IOP, Kraków. http://www.iop.krakow.pl/ssaki/Gatunek.aspx?spID=28 (access on 05.10.2016) [in Polish]

STOLARZ P. \& LESIŃSKI G. 1998. Vertebrates of Jan III Sobieski reserve in Warsaw. In: BARCZAK T. \& INDYKIEWICZ P. (ed.), Urban fauna. Wydawnictwa Uczelniane ATR, Bydgoszcz: 245-248. [in Polish with English summary]

StOlARZ P. \& LESIŃSKI G. 2012. Vertebrates In Diet of Tawny Owl Strix aluco in nature reserve „Bagno Jacka” and surrounding area. Kulon 17: 107-110. [in Polish with English summary]

ZuB K. 2016. Water vole Arvicola terrestris (Linnaeus, 1758). Atlas of Polish mammals. IOP, Kraków. http://www.iop.krakow.pl/ssaki/Gatunek.aspx?spID=66 (access on 05.10.2016) [in Polish]

ŻMIHORSKI M., GRYZ J., KRAUZE-GRYZ D., OLCZYK A. \& OsoJCA G. 2011. The Tawny owl Strix aluco as a material collector in faunistic investigations: the case study of small mammals in NE Poland. Acta Zoologica Lituanica 21: 185-191.

\section{STRESZCZENIE}

\section{[Drobne ssaki w diecie sów w Mazowieckim Parku Krajobrazowym i na terenach przyległych]}

W celu określenia struktury zgrupowań drobnych ssaków analizowano dietę sów (puszczyka Strix aluco, uszatki Asio otus i płomykówki Tyto alba) na 32 stanowiskach zlokalizowanych w Mazowieckim Parku Krajobrazowym i na jego obrzeżach. W latach 1993- 
2016 zebrano materiał zawierający łącznie 5728 ofiar kręgowych, wśród których było 4001 ssaków. Wykazano pięć gatunków ryjówkokształtnych, sześć - nietoperzy, 14 - gryzoni i jeden gatunek z rzędu drapieżnych. Spośród ssaków stwierdzonych w diecie puszczyka największy udział miała nornica ruda Myodes glareolus. Płomykówka chwytała najczęściej nornika zwyczajnego Microtus arvalis i ryjówkę aksamitną Sorex araneus, natomiast uszatka nornika zwyczajnego i nornika północnego Microtus oeconomus. Wymienione gatunki oraz mysz leśna Apodemus flavicollis i mysz polna A. agrarius dominują w zgrupowaniach drobnych ssaków na terenie badań. Odnaleziono jedno stanowisko zębiełka białawego Crocidura leucodon na zachodniej granicy jego zasięgu w Polsce. Udział nietoperzy w diecie puszczyka był niski (0,5\% ssaków), a najczęściej łowionym gatunkiem był gacek brunatny Plecotus auritus (9 na 17 osobników). Stwierdzono, że orzesznica Muscardinus avellanarius występuje w lasach południowej części Mazowieckiego Parku Krajobrazowego, a w odpowiednich środowiskach jest stosunkowo często łowiona przez puszczyka. Udziały nornika północnego, nornika burego Microtus agrestis i orzesznicy w diecie sów były większe w południowej części terenu badań, oddalonej od aglomeracji warszawskiej. 